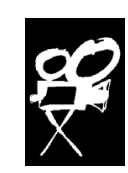

Studia

Filmoznawcze

Wrocław 2019

\title{
ŚWIĘCI W FILMIE. WSTĘP
}

DOI: $10.19195 / 0860-116 X .40 .2$

Kino pokazujące chrześcijańskich świętych jest zjawiskiem niemal tak dawnym jak sam wynalazek kinematografu: już w 1897 roku na francuskich ekranach pojawiły się pierwsze Żywoty i Pasje Chrystusa, w 1900 roku Georges Méliès w dziesięciominutowym filmie opowiedział, wykorzystując efekty specjalne, dzieje św. Joanny d'Arc od pierwszych objawień archanioła Michała aż po jej męczeńską śmierć na stosie i apoteozę. W ciągu ponad stu dwudziestu lat postaci z kart Biblii i chrześcijańscy święci, kanonizowani przez kościoły czy po prostu uznawani za bohaterów wiary, stali się protagonistami tysięcy filmów. Niektóre z nich były tworzone na wzór literackich hagiografii, pobożnych opowieści, służących umocnieniu w wierze, inne utwory opowiadały historie ludzi oddanych Bogu, próbując zgłębiać ich motywacje i duchowość, bez ulegania upraszczającym tendencjom, jeszcze inne opowiadały o świętych anonimowych, fikcyjnych.

Wśród filmów o świętych znajdują się ekranizacje Nowego Testamentu, przede wszystkim Ewangelii i Dziejów Apostolskich: to te księgi, ubarwiane nieraz treściami czerpanymi z chrześcijańskich apokryfów, mówią o Maryi Matce Jezusa i apostołach, z których na pierwszy plan wysuwają się Piotr, Paweł i Jan. Literatura hagiograficzna - dawna i nowa - inspirowała twórców kina do opowiadania o świętych, których intensywność życia niekoniecznie przekłada się na filmową popularność. Można zrozumieć powstanie licznych filmów fabularnych o św. Janie Pawle II, papieżu tak różnym od swych poprzedników, czy ekranowych biografii św. Joanny d'Arc oraz św. Franciszka z Asyżu, dzierżących palmę pierwszeństwa wśród filmowych świętych, o św. Mikołaju, który w filmowych wizjach przestał być świętym biskupem, ale zaskakiwać powinna wyjątkowo skromna filmografia św. Ignacego z Loyoli, jakże barwnej postaci założyciela jezuitów!

Filmowe opowieści o ludziach wiary, zarówno realistyczne, jak i nabierające cech mitologicznych, uznanych oficjalnie przez Kościół czy powszechniej niezna- 
nych, zawdzięczamy często twórcom wielkim, choć niekoniecznie deklaratywnie chrześcijańskim: losy Joanny d'Arc opowiadali Carl Theodor Dreyer, Robert Bresson i Gleb Panfiłow. Biedaczynę z Asyżu pokazywali Roberto Rossellini, Franco Zeffirelli oraz Liliana Cavani, która wracała doń trzykrotnie w odstępie niemal półwiecza. Filmowe zainteresowanie świętymi jest zresztą ponadwyznaniowe: Car Pawła Łungina przedstawia męczeństwo prawosławnego metropolity Filipa, Tarkowski opowiada o innym świętym prawosławia - Andrieju Rublowie. Choć w teologii ewangelickiej odmienna jest koncepcja świętości człowieka, to przecież w kategoriach hagiografii należałoby potraktować film Erica Tilla o pastorze Dietrichu Bonhoefferze, męczenniku nazizmu! Włoskie stacje telewizyjne, publiczne i prywatne, od kilku dziesięcioleci dostarczają widzom kolejne filmy fabularne o świętych dawnych (Barbara, Augustyn z Hippony, Rita z Cascii, Filip Neri...) i nowszych (Józefina Bakhita, Jan XXIII, Ojciec Pio...). Obok popularnych produkcji telewizyjnych można napotkać ambitne filmy sygnowane przez Xaviera Beauvois (Ludzie Boga) czy Krzysztofa Zanussiego, który jako pierwszy polski reżyser podjął się stworzenia filmów o polskich świętych - Maksymilianie Kolbem, bracie Albercie Chmielowskim oraz Janie Pawle II (ten film powstał na samym początku pontyfikatu, niemal ćwierć wieku przed wołaniem „Santo subito!”). Niestety, polska kinematografia nie może się pochwalić udanymi filmami fabularnymi o świętych: niedawne filmy o Maksymilianie Kolbem czy Karolinie Kózkównie powstawały raczej po to, by dostarczyć pobożnie nastawionym widzom budujących przykładów, bez zwrócenia wystarczającej uwagi na kinematograficzną jakość przedsięwzięcia.

Od dwudziestu lat - z zauważalnym opóźnieniem wobec piśmiennictwa zachodniego - rozwija się także w Polsce wspólny nurt dwóch dyscyplin, filmoznawstwa i teologii, dotąd rzadko się stykających. Filmoznawcy w swoich badaniach zaczęli uwzględniać bogaty świat filmów o tematyce religijnej, do początku lat dziewięćdziesiątych XX wieku właściwie nieobecnych na polskich ekranach, teolodzy swoimi analizami zaczęli obejmować filmy, a więc teksty audiowizualne $\mathrm{z}$ reguły przecież powstające z motywacji komercyjnej, a nie religijnej. Kompetencje odpowiednie obu obszarom owocują pogłębioną wrażliwością, która z jednej strony pozwala na właściwe rozumienie przedstawianych postaci, a z drugiej na poprawne odczytanie elementów języka filmowego. Niniejszy tom „Studiów Filmoznawczych" dokumentuje kolejny etap tego potrzebnego dialogu, istniejącego między kulturą a wiarą.

ks. Marek Lis 